\title{
REVIEWS.
}

Wells and Springs of Worcestershire. By L. Richardson, Mem. Geol. Survey. pp. v +219 , with 1 plate and 3 text-figs. 1930. Price $4 s$.

THIS memoir is written on the now well-known standard plan, 1 which has proved so useful in the case of many other counties in recent years. It is enriched by a very large number of analyses made by the County Analyst, Mr. C. C. Duncan and a contribution on rainfall by Mr. B. Brotherton. In connection with Worcestershire and its water supply the thoughts of most readers will naturally turn first to the famous Malvern waters, and it is curious to find that apart from these famous springs, the Malvern area has actually had in the past grave difficulties to contend with in providing an adequate supply for general purposes, owing to the concentration of population on a high, narrow ridge, the Malvern Hills, with a very inadequate gathering ground, and specially active evaporation, owing to its isolated position and geological structure : only a very small proportion of the rather low rainfall is available as springs. The rest of the county is less spectacular from this point of view, as plenty of water is generally available in the Trias, though the Lias area in the south-east is not well supplied, being mostly clay: the.water from various limestones, in limited quantity, is often very hard.

\section{OBITUARY. \\ Thomas Crosbee Cantrill, B.Sc., F.G.S.}

1867-1931.

By the death of Thomas Crosbee Cantrill on 3rd April, 1931, the sciences of geology and archaeology have alike suffered a serious loss. Born on the 20th November, 1867, he was educated at the Edward VI Grammar School, at Stonebridge, and afterwards at Mason's College, Birmingham, graduating B.Sc. in 1891. During a brief scholastic career he investigated with success the structure of the Forest of Wyre Coalfield, for which work he was awarded the Heslop Gold Medal in 1895, and in 1896 joined the staff of the Geological Survey. For fourteen years he served as geologist in the investigation of the South Wales Coalfield, and, in co-operation with the late Sir Aubrey Strahan and others, was part author of nine memoirs and one-inch maps of the coalfield.

In 1910, on the completion of this survey, he was transferred to the Midlands and was occupied in the Lichfield area until his appointment as District Geologist in 1914.

During the war he prepared several of the Special Reports on Mineral Resources and in 1919 resumed normal field-work in North 
Wales and the West Midlands. In 1921 his activities were interrupted by a breakdown in health from which he recovered sufficiently to overtake the arrears of publication due to the war. The concentrated effort involved in the completion of this task allowed him little opportunity for rest or recreation.

He retired in November, 1927, to his native county of Worcestershire, and devoted his well-earned leisure to the study of local archaeology; a subject in which he had always evinced a great interest. He contributed sever alpapers to Archaeologia Cambrensis and other antiquarian journals; especially on the subject of prehistoric cooking places.

Cantrill was always a keen geologist, a good observer, and a most painstaking and accurate recorder of facts, both in his published work and in his conscientious and detailed mapping. He endeared himself to his colleagues, as indeed to all who knew him well, by his kindly and courteous nature and, though of a somewhat retiring disposition, was well known to many as a man of wide experience and sound judgment as a coalfield geologist. His Handbook on Coal Mining is still a readable and reliable guide to the subject. His loss will be keenly felt by all those who had the good fortune to be counted among the number of his friends.

R. W. P.

\section{CORRESPONDENCE.}

\section{LARGER FORAMINIFERA FROM THE TERTIARY OF SOMALILAND.}

SIR,-Since Mr. Brighton could answer my letter (in your issue for April), before it was published, while I only see his reply after it appears in print, I hope that you will allow me to say a few words more.

What I protested against was Messrs. Nuttall and Brighton's sweeping statement (backed by a very one-sided selection of data) that I had had "no justification" for referring the Kohat Shale to the Laki. I would therefore point out that Mr. Brighton has now had to admit that " characteristically Lower Eocene forms" (hitherto totally ignored by himself and his colleague) had been reported throughout the Kohat Shale; and whatever else he may say in his letter (apparently trying to defend the statement against which I protest) he concludes by admitting that, at present, the age of the Kohat Shale fauna "must remain in doubt".

I think this bears out my protest. Mr. Brighton's admissions show that I did have some justification for referring the Kohat Shale to the uppermost Laki.

LEITH ForT,

L. M. Davies.

EDINBURGH.

11 th April, 1931. 